\title{
THE OCCURRENCE OF THE SMOOTH SAND- EEL, GYMNAMMODYTES SEMISQUAMATUS (JOURDAIN), IN THE PLYMOUTH AREA, WITH NOTES ON G. CICERELUS (RAFINESQUE), AND G. CAPENSIS (BARNARD)
}

\author{
By P. G. Corbin, B.A. \\ Zoologist at the Plymouth Laboratory
}

\section{Distribution and Plymouth Records of GyMNAMMODYTES SEMISQUAMATUS}

Gymnammodytes semisquamatus (Jourdain), the smooth sand-eel occurring along the Atlantic seaboard of north-western Europe, has been separated by Duncker \& Mohr (I939) as a distinct species from the Mediterranean smooth sand-eel, G. cicerelus $^{1}$ (Rafinesque). Until Raitt's discovery (1934, I935) of the abundance of $G$. semisquamatus ${ }^{2}$ in Scottish waters, only six specimens had been recorded farther north than the English Channel:

Shetlands, one specimen as Ammodytessiculus, Günther (1867). Southern Norway, five specimens as $A$. cicerellus, Collett (1904), Grieg (I9I2). It has recently been identified by Poll (1947) from the West Hinder Bank in the southern North Sea (seventeen specimens, I5 May 1907). It does not occur in Swedish waters as stated in Corbin \& Vati (1949, pp. 289-90) on Lönnberg's (1915) authority. When this was written it had unfortunately not been possible to consult Lönnberg (I915), and the error is a repetition of one occurring in Raitt's papers (1934, 1935).

The species has, however, long been known from the southern half of the mouth of the English Channel in the St Malo area, and along the Atlantic coast-line of France, Spain and Portugal, although not validly distinguished from Gymnammodytes cicerelus until the publication of Duncker \& Mohr's study:

St Malo area, as Ammodytes semisquamatus, Jourdain (1879), Moreau (I89I). Atlantic coast, as A. cicerellus, France, Acloque (1900), Spain and Portugal, de Buen (I935), Gonçalves (I942).

Gymnammodytes semisquamatus was first identified in the Plymouth area in July 1947, and has since been taken during all months of the year.

It also occurs in the Irish Sea off the Isle of Man, a single specimen having been identified among a small part of the collection of the Marine Biological

${ }^{1}$ Dr E. Trewavas, British Museum (Natural History), has kindly pointed out that cicerelus is the original spelling of Rafinesque.

${ }^{2}$ Recorded as Ammodytes cicerellus, before Duncker \& Mohr's separation of the two species. 
Station, Port Erin, Isle of Man. ${ }^{1}$ It was taken locally, although the date and precise place of capture were not recorded.

Raitt's records from Scottish waters, this single specimen from the Irish Sea, and the occurrence of the species in the Plymouth area indicate a continuous distribution from the Faroes, southwards along the west coast of Scotland, through the Irish Sea to the Western Channel mouth, joining thence with the previously known distribution along the Atlantic coast-line of France, Spain and Portugal.

The use of a trawl with a covered cod-end will, no doubt, reveal the species to be fairly widely distributed in the Irish Sea and Celtic Sea. It will be of interest to know whether it also occurs along the Atlantic coast of Ireland.

The following are the records from the Plymouth area: ${ }^{2}$

Twelve specimens were caught in the trawl on eight occasions (Mar. 1949, May 1949, June 1948 and 1949, July 1947, Aug. 1949, Sept. 1949). Forty-three specimens were taken by the dredge in shell gravel on seventeen occasions, once in Bigbury Bay and sixteen times from the Eddystone shell gravel (Jan. I949, Feb. 1949, March 1948 and 1949, July 1949, Sept. 1948, Oct. I947, Nov. 1947-9, Dec. 1948). Not infrequently, however, none has been caught during a day's dredging for Amphioxus on this ground. Ninety-six specimens were taken in six Agassiz trawl hauls on the Eddystone shell gravel (Feb. and Apr. 1949). This number is noteworthy since the Agassiz trawl can be towed for very little longer than $5 \mathrm{~min}$. on this ground owing to its small area between the submerged long sharp reefs standing out from the main Eddystone Rock. Eight specimens were caught in a short trawl haul to the east of the Eddystone lighthouse, with the codend of the trawl covered with small mesh netting ( $\frac{3}{8}$ in. bar), as used in the shellgravel dredge and the Agassiz trawl (May 1949). One specimen was found in a whiting's stomach (Apr. I949) and seven specimens in perfect condition were taken from the stomach of a turbot trawled to the south-west of Looe (May 1949).

Several observations may be made from these records. Before the present interest developed, the Agassiz trawl was seldom used on the Eddystone shellgravel patch. Moreover, in the past, while sorting dredge hauls of shell gravel at sea, all attention was concentrated on securing Amphioxus; sand-eels, for which there was no special demand, are unlikely to have received the same attention. They are frequently damaged when caught in the dredge and may have been discarded for this reason, or, if brought in to the laboratory, were probably not closely examined. It seems reasonable then to infer that the species has previously been overlooked in the Plymouth area, and is not a recent arrival.

The infrequent captures in the trawl of very few specimens of Gymnammodytes semisquamatus reveal that the normal mesh size of the cod-end does not effectively retain sand-eels. This is amply borne out by the fact that the great

1 The writer is indebted to $\mathrm{Mr} \mathrm{J}$. R. Bruce for kindly providing this material for examination.

2 The writer's sincere thanks are due to Lieut.-Commander C. A. Hoodless, D.S.C., R.N.R., and $\mathrm{Mr}$ W. J. Creese, and to the members of the crews of R.V. Sabella and M.F.V. Sula for their constant watch for, and help in securing, specimens. 
majority of Raitt's very large collection of Ammodytidae were caught while trawling with a small-mesh cover to the cod-end. ${ }^{1}$

The body form of a sand-eel and its ability to burrow in the dense medium of sand or shell gravel conceivably give it a greater chance than other 'trawl fish' of successfully escaping from the violent hurly-burly occurring in the cod-end of a trawl when fishing.

From the records of the area, it also appears that $G$. semisquamatus is an off-shore species with a preference for shell gravel grounds. Shore seining for sand-eels is commonly practised in many districts, but no specimens of G. semisquamatus have been seen during examination of a number of seine catches from Salcombe and the Exe estuary; in them Ammodytes tobianus was abundant, together with comparatively few $A$. lanceolatus. Nor has the species been taken by digging or hooking on the shore at several localities in South Devon and North Cornwall where both A. tobianus and A. lanceolatus were found. ${ }^{2}$

Although the actual numbers of $G$. semisquamatus caught in the dredge are low, they represent a considerable density of the species in the shell gravel in relation to the small volume of soil obtained by a dredge haul. The larger numbers caught by the Agassiz trawl on the shell gravel support this indication of a concentration, and it is further emphasized by the absence of G. semisquamatus from numerous Agassiz hauls made on other grounds in the Plymouth area including a number of 'control' hauls made close in to the Eddystone, but not actually on the shell gravel. The records of trawl-caught specimens show, however, that the species is not confined to the area of shell gravel. In relation to the above observations, the selectivity of the small mesh of the Agassiz trawl and the dredge must obviously be borne in mind. It is to be expected that more extensive use of a covered cod-end on the trawl will give fuller information on the distribution of the species.

A further point of interest is a seasonal alternation of the occurrence of trawled specimens (including those from the turbot and whiting stomachs) and dredged specimens. The occurrences are shown by months in Table I. Specimens caught by the Agassiz trawl and the small-mesh cod-end are not included since so few hauls were made with these nets.

It may be argued from the small number of records that this difference is fortuitous. On the other hand, the laboratory's two ships trawl throughout the year, and although not as frequent as trawling, dredging is necessitated by the constant demand for Amphioxus, whenever weather conditions are calm enough to work close to the Eddystone on the shell gravel. The seasonal difference

1 Ascertained, by courtesy of Dr C. E. Lucas, from records at the Marine Laboratory, Scottish Home Department, Aberdeen.

${ }^{2}$ In the course of collecting, Gymnammodytes semisquamatus and Ammodytes lanceolatus have been taken together in the same haul. The characteristic lateral line of semisquamatus immediately distinguishes it. Although it has not been caught with $A$. tobianus, the same feature would also certainly distinguish it in this combination of species. 
evident in Table I derives then from all-the-year-round sampling and in this event would appear to be a real one.

TABLE I. MONTHS IN WHICH GYMNAMMODYTES SEMISQUAMATUS HAS been taken in the Plymouth Area by Trawl and Dredge, July 1947 TO NOVEMBER I949

\begin{tabular}{cc} 
Dredge & Trawl \\
Jan. & - \\
Feb. & Mar. \\
Mar. & Apr. \\
\hline & May \\
\hline- & June \\
July & July \\
Sept. & Aug. \\
Oct. & Sept. \\
Nov. & - \\
Dec. & -
\end{tabular}

There is thus a tentative indication of a winter concentration of the species in the shell gravel and a summer dispersal away from it. From examination of the gonad condition of the material, it would appear that the winter concentration in the shell gravel is associated with spawning. Very much fuller data are obviously necessary for confirming any of these indications; it is felt, however, that they are of some value in view of the lack of any knowledge about the life history of the North Atlantic smooth sand-eel.

The Number of Vertebrae in the Three Species of GyMnammodytes The number of vertebrae in G. semisquamatus from this area ${ }^{1}$ is given in Table II for comparison with counts of specimens from Scottish waters (Corbin \& Vati, I949). There is very close agreement between the means of these two samples. Table II also contains vertebral counts of G. cicerelus, the Mediterranean smooth sand-eel. Previous vertebral-count data of the species (Fage, I9I8; Duncker \& Mohr, 1939) relate to a small number of specimens. The present sample of thirty-nine specimens $(6.8-10.0 \mathrm{~cm}$.) from the Naples $\operatorname{area}^{2}$ is large enough to give a mean value, and it can be seen that this is not far removed from that of $G$. semisquamatus. It would be of interest to obtain further vertebral counts of $G$. cicerelus from other Mediterranean localities to examine whether there is extensive variation between different populations, as, for example, in Ammodytes marinus (see references in Corbin \& Vati, I949, Table II, p. 302), and in particular whether the vertebral number of the Black Sea population differs greatly from that of the Mediterranean population.

1 The writer's sincere thanks are due to Surgeon-Commander D. R. F. Bertram, O.B.E., R.N., Royal Naval Hospital, Stonehouse, for the provision of beautifully clear X-ray plates of these specimens from which the counts were made.

2 The writer is much indebted to Dr R. Dohrn, Director of the Stazione Zoologica, for this material. 
Vertebral counts of fifty-nine specimens of the South African smooth sand-eel, Gymnammodytes capensis (Barnard, 1927), of 6.9-9.5 cm. length, are also included in Table II. ${ }^{1}$ They were collected by R.R.S. Discovery in Elephant Bay, Angola, South Africa (Station 27I, 29 July I927, seine net, 5-0 m. depth). The wide difference between the vertebral counts of G. semisquamatus and G. capensis is remarkable in view of the extremely close similarity of external features in the two species. The specimens of $G$. capensis were very carefully compared with G. semisquamatus from this area and from Scottish waters, and it was found

TABle II. The Number of Vertebrae In GYMNAMMODYTES SEMISQUAMATUS, G. CICERELUS AND G. CAPENSIS

\begin{tabular}{|c|c|c|c|c|}
\hline \multirow{2}{*}{$\begin{array}{l}\text { No. of vertebrae } \\
\text { (including } \\
\text { urostyle) }\end{array}$} & \multicolumn{2}{|c|}{ G. semisquamatus } & \multirow[b]{2}{*}{ G. cicerelus } & \multirow[b]{2}{*}{ G. capensi } \\
\hline & Plymouth & Scotland & & \\
\hline 57 & .. & .. & .. & 5 \\
\hline 58 & .. & .. & .. & 23 \\
\hline 59 & .. & . & . & 22 \\
\hline 60 & .. & .. & .. & 9 \\
\hline $6 \mathrm{I}$ & $\cdots$ & . & .. & . \\
\hline 62 & .. & .. & .. & .. \\
\hline 63 & .. & .. & .. & .. \\
\hline 64 & . & $\cdots$ & $\cdots$ & .. \\
\hline 65 & $\because$ & I & 7 & .. \\
\hline 66 & 2 & I & I7 & . \\
\hline 67 & I5 & Io & I3 & .. \\
\hline 68 & 43 & 20 & 2 & .. \\
\hline 69 & 33 & I5 & .. & . \\
\hline 70 & $\mathrm{I}_{3}$ & 4 & .. & .. \\
\hline 71 & I & . & . & .. \\
\hline 72 & I & . & .. & . \\
\hline $\begin{array}{l}\text { Total no. of } \\
\text { specimens }\end{array}$ & 108 & $5 \mathrm{I}$ & 39 & 59 \\
\hline Mean vertebral no. & $68 \cdot 44$ & $68 \cdot 16$ & $66 \cdot 26$ & $58 \cdot 59$ \\
\hline$\sigma_{\text {mean }}$ & \pm 0.098 & $\pm 0.144^{2}$ & $\pm 0.13 I$ & \pm 0.113 \\
\hline$\sigma$ & I.0I7 & $\mathrm{I} \cdot 027^{2}$ & 0.819 & 0.857 \\
\hline
\end{tabular}

that the two species could not be reliably distinguished by external features other than the numerical differences, noted by Duncker \& Mohr (1939), of the number of fin-rays and the number of ventral pores in the lateral line. No differences of pigmentation were observed. Duncker \& Mohr (1939) also distinguish $G$. semisquamatus and $G$. capensis by differences of the position of the tip of the pectoral fin and the end of the ventro-lateral skin-fold in relation to the line of insertion of the first ray of the dorsal fin. These differences could not, however, be confirmed in the above material. In the great majority of the G. semisquamatus and G. capensis examined, both the tip of the pectoral

\footnotetext{
1 The writer is much indebted to Dr E. Trewavas, British Museum (Natural History), for the loan of the specimens for examination and of excellent X-ray plates from which the counts were made.

${ }^{2}$ Under G. semisquamatus, in Corbin \& Vati, I949, Table II, p. 302, the values of \pm 0.127 and 0.901 should be amended to read \pm 0.144 and I.027 respectively.
} 
and the end of the ventro-lateral skin-fold were in line with the insertion of the first ray of the dorsal fin; in some few specimens they extended very slightly beyond this line or were just short of it, by an interval of less than $\mathrm{I} \cdot 0 \mathrm{~mm}$. The interval in Duncker \& Mohr's figs. $4 a$ and $4 c$ is considerably larger than this. ${ }^{1}$ It is possible that there is some variation of these relative lengths with size, although no evidence of this was seen in the material examined. Nor, as these authors state, was the ventro-lateral skin fold of $G$. capensis observed to be less well developed than in G. semisquamatus. The external non-metameric differences between these two species appear therefore to be of little or no value for specific identification.

It may be added that, in the Mediterranean and Black Sea specimens of G. cicerelus, the tip of the pectoral extended slightly beyond (not more than $\mathrm{I} \cdot 0 \mathrm{~mm}$.) the line of the first ray of the dorsal. This is in agreement with Duncker \& Mohr's description, although the pectoral is well short of this line in their fig. $4 b^{1}$.

\section{SUMMARY}

Gymnammodytes semisquamatus, the North Atlantic smooth sand-eel, has a continuous distribution from southern Norway to the southern Atlantic coast-line of Spain. Its occurrence in the Irish Sea and in the Plymouth area are new records. In the latter area it is an off-shore species, apparently concentrating in shell gravel in winter for spawning. It has a mean vertebral number of slightly over 68 (Plymouth and Scottish specimens). A small sample of the Mediterranean species, G. cicerelus, gives a mean of just over 66, while the South African species, G. capensis, which is indistinguishable from G. semisquamatus by external non-metameric characters, has a much lower mean of $58 \cdot 5$.

\section{REFERENCES}

Acloque, A., I900. Faune de France. Tome I. Mammifères, Oiseaux, Poissons, Reptiles, Batrachiens, Protochordes. Paris I900. 540 pp.

BARNARD, K. H., I927. Diagnoses of new genera and species of South African marine fishes. Ann. Mag. Nat. Hist., Ser. 9, Vol. xx, pp. 66-79.

Buen, F. DE, I935. Fauna Ictiológica. Catálogo de los peces Ibéricos: aguas dulces, pelágicos y de los abismos próximos. Primera parte. Notas Inst. Esp. Oceanog., No. 88 , pp. I-I49.

Collett, R., I904. Meddelelser om Norges Fiske i Aarene I884-I90I. (3die Hovedsupplement til 'Norges Fiske'). II. Forh. VidenskSelsk. Krist., 1903, No. 9, pp. I-I75.

Corbin, P. G. \& Vati, V., I949. The post-larval sand-eels (Ammodytidae) of the Celtic Sea and Plymouth area. Fourn. Mar. Biol. Assoc., Vol. xxviII, pp. 287-313.

Duncker, G. \& Mohr, E., I939. Revision der Ammodytidae. Mitt. Zool. Mus. Berl., Bd. 24, Heft I, pp. 8-3I.

${ }^{1}$ Duncker \& Mohr's (1939) fig. 4 is approximately natural size for adults of the three Gymnammodytes species. 
FAGe, L., I918. Shore fishes. Rep. Danish Oceanogr. Exped. Medit., No. 4, Vol. II (Biology), A. 3, pp. I-I54.

Gonçalves, B. C., I942. Colecção oceanográfica de D. Carlos I. Catálogo dos peixes. Trav. Sta. Biol. Marit. Lisbonne, No. 46, pp. I-I08.

Grieg, J. A., I9I2. Icthyologiske notiser III. Bergens Mus. Aarb., I9II, Nr. 6, pp. I-38.

GÜNTHer, A., I867. Additions to the British Fauna. Ann. Mag. Nat. Hist., Ser. 3, Vol. xx, pp. 288-9I.

Jourdain, S., I879. Sur les Ammodytes des côtes de la Manche. Revue de Sciences Naturelles, T. I, pp. 203-10.

LÖNNBERG, E., I9I5. Sveriges Ryggradsdjur. 3. Kraldjur, Groddjur, Fiskar. Stockholm I915, 33I pp.

Moreau, E., I891. Histoire naturelle des poissons de la France. Supplément. Paris I89I, I44 pp.

Poll, M., 1947. Faune de Belgique. Poissons Marins. Bruxelles. 452 pp.

RAITT, D. S., I934. A preliminary account of the sand eels of Scottish waters. Fourn. Cons. Int. Expl. Mer, Vol. Ix, pp. 365-72.

1935. The occurrence of four species of sand eels, of economic importance, in Scottish waters, one of which is new to science. Scot. Nat., No. 2I I, pp. 6I-2. 